\title{
Intake, performance and nutrient digestibility of sheep fed sugarcane treated and ensiled with calcium oxide or urea ${ }^{1}$
}

\author{
Albertí Ferreira Magalhães ${ }^{2}$, Aureliano José Vieira Pires ${ }^{3,5}$, Gleidson Giordano Pinto de \\ Carvalho ${ }^{4,5}$, Fabiano Ferreira da Silva ${ }^{3,5}$, Carlos Souza Nascimento Filho ${ }^{3,6}$, Aline Oliveira \\ Carvalho 3,7
}

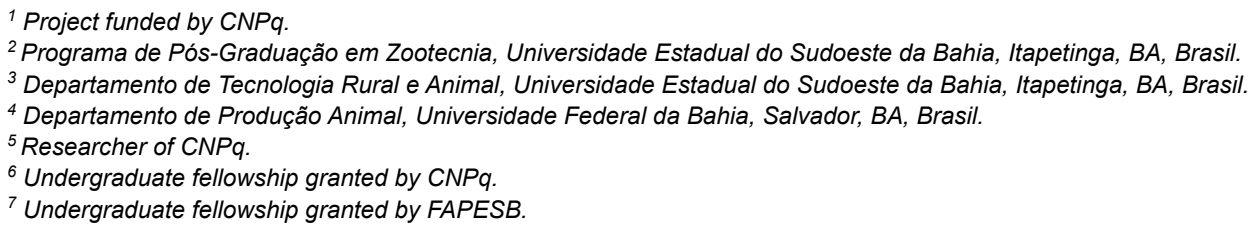

ABSTRACT - The objective of this study was to evaluate intake, performance and nutrient digestibility of sheep supplemented with sugarcane ensiled with four levels of calcium oxide $(0.0,0.8,1.6$ and $2.4 \%)$ and urea $(1.5 \%)$, on a natural matter basis. Twenty castrated Santa Ines lambs with $24.09 \mathrm{~kg}$ average weight were housed in individual $1.5 \mathrm{~m}^{2}$ pens, distributed in a completely randomized design. The diet supplied had a roughage:concentrate ratio of 70:30 and the experimental period lasted 77 days, of which 14 days were used for adaptation to the diet and three 21 -day periods for data collection. No differences were observed for the average daily intake of dry matter, ether extract, neutral detergent fiber, neutral detergent fiber corrected for ash and protein, total carbohydrates, hemicellulose and total digestible nutrients. The treatment with urea showed differences for the intake ( $\mathrm{kg} /$ day) of crude protein, acid detergent fiber and non-fibrous carbohydrates. There was no effect of diets on the digestibility of dry matter, ether extract, neutral detergent fiber, acid detergent fiber or total digestible nutrients, but there was a quadratic effect for total carbohydrates and increasing linear effect for non-fibrous carbohydrates. The calcium intake increased as the levels of calcium oxide in the sugarcane were elevated. The calcium:phosphorus ratio in the silage of calcium oxide was different from the silage with urea and control. No effect was observed for the performance characteristics of sheep. Sugarcane silages with calcium oxide levels of up to $2.4 \%$ or with urea do not improve the intake or weight gain of sheep.

Key Words: calcium/phosphorus ratio, chemical additives, lime, roughage, silage

\section{Introduction}

The complexity of the digestive tracts of ruminants makes them of great economic value because of their potential in utilizing uncommon feedstuffs in the feeding of non-ruminants and men. This is true not only because these animals still depend on the physical and physiological effects of the fiber in the gastrointestinal tract, but mostly because of the costs that the feedstuffs can present (Bezerra et al., 2004).

The value of a feedstuff depends mostly on the level of nutrients it contains, the amount ingested voluntarily by the animal and the digestibility and, or, degradability of the nutrients consumed. The efficient evaluation of a feedstuff to determine the prediction of the animal response is based on knowing the daily amounts of digestible protein and energy that the animal can obtain from this feed. Thus, to know the potential value of a feedstuff, through rumen degradation, allows for its rational use (Cabral et al., 2005).
Sugarcane has been utilized as roughage in the finishing of cattle for presenting positive attributes such as easy implantation, few crop treatments, high productivity and good quality in the period of pasture shortage (Resende et al., 2005). It can be conserved and utilized as silage, in spite of the drawbacks of high content of soluble sugars with rapid proliferation of yeasts and production of ethanol and carbonic gas (Resende et al., 2005).

It has been observed that the use of several additives in sugarcane has brought great benefits such as increase of the nitrogenous fraction (Pires et al., 2004b; Carvalho et al., 2006a; Amaral, 2007). However, the use of alkaline additives such as sodium hydroxide and calcium oxide does not contribute to the increase of nitrogen uptake, sometimes triggering a greater effect of hydrolysis on the cell wall of roughages, improving the fiber digestibility and intake (Andrade et al., 2001; Oliveira et al., 2007a, 2007b).

The objective of this study was to evaluate the intake and apparent digestibility of nutrients as well as the 
performance of sheep fed sugarcane ensiled with different levels of calcium oxide or urea.

\section{Material and Methods}

The experiment was conducted in the sheep farming sector Ensaios Nutricionais de Ovinos e Caprinos (ENOC) and in the laboratory of forage and pastures of Universidade Estadual do Sudoeste da Bahia, Campus Itapetinga, Bahia State, Brazil.

The experimental design was completely randomized, with five treatments (doses of $0.0 ; 0.8 ; 1.6$ and $2.4 \%$ calcium oxide $(\mathrm{CaO})$ or $1.5 \%$ urea in the natural matter), all applied at the moment of ensilage.

Twenty male castrated Santa Ines lambs at four months of age and $24.09 \mathrm{~kg}$ average weight were housed in individual $1.5 \mathrm{~m}^{2}$ pens with previously swept cemented floor, fed diets containing $70 \%$ sugarcane silage with different doses of $\mathrm{CaO}$ or urea and $30 \%$ concentrate in the natural matter (Table 1). Pens were provided with troughs

Table 1 - Percentage of ingredients and concentrate of experimental diets $(\%$ in the dry matter)

\begin{tabular}{|c|c|c|}
\hline Ingredient & Concentrate & Diet \\
\hline Sugarcane $^{1}$ & - & 70.0 \\
\hline Corn & 63.30 & 19.0 \\
\hline Soybean meal & 26.70 & 8.0 \\
\hline Common salt & 6.60 & 2.0 \\
\hline Mineralized salt ${ }^{2}$ & 3.40 & 1.0 \\
\hline Total & 100 & 100 \\
\hline
\end{tabular}

${ }^{1}$ Sugarcane with different levels of calcium oxide $(0.0,0.8,1.6$ and $2.4 \%$ in natural matter) and addition of $1.5 \%$ urea (\% natural matter).

${ }^{2}$ Amount per kg of product: Ca - 155 g; P - 65 g; S - 12 g; Mg - 6 g; Na - 115 g; Co - 175 mg; Cu - 100 mg; I - 175 mg; Mn - 1400 mg; Ni - 42 mg; Se - 27 mg; $\mathrm{Zn}-6000 \mathrm{mg} ; \mathrm{Fe}-1000 \mathrm{mg}$. and drinkers in the front. The sugarcane was chopped to particles of 1 to $2 \mathrm{~cm}$ and mixed on a masonry floor for complete homogenization. After, they were weighed, separated in amounts of $140 \mathrm{~kg}$, treated according to the doses of calcium and urea and subsequently conditioned in $200 \mathrm{~L}$ barrels, which were sealed with double-sided canvas of 200 micron thickness, keeping a density of $700 \mathrm{~kg}$ natural matter $/ \mathrm{m}^{3}$.

After the compaction and before closing the silos, samples of approximately $500 \mathrm{~g}$ were collected from the center of each silo, at a depth of approximately $40 \mathrm{~cm}$. At the end of 30 days after closing the silos, they were reopened and a sample of each one was collected, as was done during the closure.

The sugarcane variety utilized was RB 72.454; in the treatments with calcium oxide, it was corrected with $1.0 \%$ urea (a mix of urea + ammonium sulfate at a 9:1 ratio), on the natural matter basis. Diets were calculated according to the NRC (2006), in order to allow for a weight gain of $150 \mathrm{~g} /$ day. The diets were balanced to contain approximately $13 \%$ crude protein and $53 \%$ total digestible nutrients, having calcium oxide or urea and the concentrate in their chemical composition (Table 2).

The experiment lasted 77 days, composed of three experimental periods of 21 days, for evaluation, weighing and collection of feces, urine and blood and 14 days for animals to adapt.

Experimental diets were supplied ad libitum, twice daily - at $07 \mathrm{~h} 00$ and $15 \mathrm{~h} 00$ - being adjusted to keep the leftovers at around $10 \%$ of the total supplied. Sample collection occurred daily during the whole experimental period (three 21-day periods), in which roughage,

Table 2 - Chemical composition of the sugarcane silage with different levels of calcium oxide $(\mathrm{CaO})$ or urea and of the concentrate, in the natural matter

\begin{tabular}{|c|c|c|c|c|c|c|}
\hline \multirow{2}{*}{ Item } & \multicolumn{4}{|c|}{ Sugarcane silage with different doses of $\mathrm{CaO}$ (in $\%$ of natural matter) } & \multirow{2}{*}{ Sugarcane silage with urea ${ }^{1}$} & \multirow{2}{*}{ Concentrate } \\
\hline & 0.0 & 0.8 & 1.6 & 2.4 & & \\
\hline Dry matter & 20.1 & 22.3 & 23.1 & 23.2 & 20.7 & 88.3 \\
\hline Crude protein ${ }^{2}$ & 1.15 & 1.23 & 1.15 & 1.10 & 14.9 & 20.0 \\
\hline Neutral detergent fiber ${ }^{2}$ & 74.0 & 58.6 & 55.1 & 48.5 & 68.6 & 16.0 \\
\hline $\mathrm{NDFap}^{2}$ & 71.1 & 55.7 & 52.4 & 45.6 & 65.6 & 12.4 \\
\hline Acid detergent fiber ${ }^{2}$ & 63.3 & 50.3 & 45.3 & 40.1 & 59.4 & 8.8 \\
\hline NDIP $^{2}$ & 059 & 0.51 & 0.50 & 0.42 & 0.81 & 12.1 \\
\hline NDIA $^{2}$ & 2.4 & 2.4 & 2.3 & 2.5 & 2.2 & 0.3 \\
\hline Ether extract ${ }^{2}$ & 1.6 & 1.8 & 1.8 & 1.8 & 1.8 & 1.2 \\
\hline Cellulose $^{2}$ & 49.0 & 40.7 & 33.1 & 31.1 & 45.1 & 12.0 \\
\hline Hemicellulose $^{2}$ & 10.7 & 8.2 & 9.8 & 8.4 & 9.2 & 7.8 \\
\hline $\operatorname{Lignin}^{2}$ & 10.3 & 8.4 & 6.8 & 5.7 & 9.5 & 9.4 \\
\hline $\mathrm{Ash}^{2}$ & 3.6 & 8.1 & 10.0 & 14.0 & 3.3 & 10.7 \\
\hline Total digestible nutrients ${ }^{3}$ & 42.8 & 54.6 & 57.3 & 62.3 & 47.0 & 73.8 \\
\hline ISDMD & 51.2 & 51.1 & 61.1 & 65.5 & 59.6 & 79.3 \\
\hline
\end{tabular}

NDFap - neutral detergent fiber corrected for ash and protein; NDIP - neutral detergent insoluble protein; NDIA - neutral detergent insoluble ash; ISDMD - in situ dry matter digestibility.

${ }^{1}$ Sugarcane with addition of $1.5 \%$ urea (\% natural matter) and calcium oxide levels applied in \% of natural matter

${ }^{2}$ Values in percentage of dry matter.

${ }^{3}$ Estimated according to the NRC (2006). 
concentrate and leftovers of each animal were collected. Samples were conditioned in plastic bags and stored in a freezer for subsequent analyses. All animals were weighed at the beginning and end of each experimental period.

At pre-drying, the samples collected were thawed, weighed and taken to an oven at $60^{\circ} \mathrm{C}$ with air circulation and renewal for 72 hours. Next, samples were maintained at room temperature for two hours, weighed and ground in a sieve with $1 \mathrm{~mm}$ screen, conditioned and identified for later analyses.

The samples collected were analyzed for the following items: dry matter (DM), total nitrogen (TN), neutral detergent fiber (NDF), acid detergent fiber (ADF), neutral detergent insoluble protein (NDIP), neutral detergent insoluble ash (NDIA), cellulose, hemicellulose, lignin, ash and ether extract (EE), according to Silva \& Queiroz (2002); neutral detergent fiber corrected for ash and protein (NDFap) according to Mertens (2002); and in situ dry matter digestibility for 48 hours (ISDMD), according to Ørskov et al. (1980).

The contents of total carbohydrates $(\mathrm{TCH})$ were estimated by the difference, adopting the following equation of Sniffen et al. (1992):

$$
\mathrm{TCH}=100-(\% \mathrm{CP}+\% \mathrm{EE}+\% \mathrm{ash})
$$

Because of the presence of urea, non-fibrous carbohydrates (NFC) were calculated in an adaptation to what was proposed by Hall (2003), as follows:

$$
\begin{gathered}
\mathrm{NFC}=100-[(\% \mathrm{CP}-\% \mathrm{CP} \text { urea })+\% \text { NDFap }+\% \\
\mathrm{EE}+\% \text { ash }]
\end{gathered}
$$

The total digestible nutrients (TDN) were calculated from the energy estimates estimated by Cappelle et al. (2001) for silages with additives.

For the evaluation of the digestibility coefficient of dry matter and other nutrients, the technique of external marker was employed, utilizing indigestible NDF as the reference. Samples of feces were collected directly from the rectum of animals in the morning and afternoon, during five consecutive days in the third experimental period. Samples of feces were conditioned in plastic bags previously identified and stored in a freezer for subsequent processing and analyses. The preparation of the composite sample was done after pre-drying and grinding the material.

To obtain the iNDF contents for estimating the fecal output, samples of the feed supplied, sugarcane and concentrate, leftovers and feces were incubated for 240 hours (Casali, 2006) in duplicate $\left(20 \mathrm{mg} \mathrm{DM} / \mathrm{cm}^{2}\right)$ in nonwoven (TNT $-100 \mathrm{mg} / \mathrm{m}^{2}$ ) textile bags, in the rumen of a crossbred steer receiving a mixed diet. After this period, bags were removed and washed in running water, and the remaining material from incubation was taken to forced- ventilation oven at $60{ }^{\circ} \mathrm{C}$ for 72 hours for determination of the indigestible dry matter (iDM) and indigestible neutral detergent fiber (iNDF).

The results were subjected to analysis of variance, performing a Dunnett test subsequently to evaluate the effect of the calcium oxide doses in relation to the urea and regression analysis for the study of the effect of $\mathrm{CaO}$ doses, at 5\% probability. Software SAEG (Sistema de Análises Estatísticas e Genéticas, version 9.1) was utilized for conducting statistical analyses.

\section{Results and Discussion}

There was no difference $(\mathrm{P}>0.05)$ between the intake values of DM, EE, NDF, NDFap, TCH, hemicellulose and TDN of the sugarcane silage with different levels of calcium oxide, in $\mathrm{kg} / \mathrm{day}$, in relation to the silage of sugarcane with urea. For the intake in percentage of live weight (LW) the same behavior was verified for EE, NDF, NDFap and ADF. The mean values for the intake of DM, NDF, NDFap, TCH, hemicellulose and TDN were of 0.683, 0.311, 0.312, 0.570, 0.064 and $0.439 \mathrm{~g} /$ day, respectively.

Ether extract presented increasing quadratic effect $(\mathrm{P}<0.05)$ of maximum intake of $0.0101 \mathrm{~kg} / \mathrm{day}$ for a dose of $1.31 \%$ calcium oxide $(\mathrm{CaO})$. The maximum hemicellulose intake presented negative quadratic effect $(\mathrm{P}<0.01)$, of $0.0518 \mathrm{~kg} /$ day at the level of $1.82 \% \mathrm{CaO}$. Total digestible nutrients presented an increasing quadratic effect $(\mathrm{P}<0.01)$ with maximum intake of $0.5253 \mathrm{~kg}$ /day at $1.40 \% \mathrm{CaO}$ (Table 3).

The intake of CP, ADF and NFC, in kg/day, was different between the silages with $\mathrm{CaO}$ and urea (Table 3). The $\mathrm{CP}$ intake presented effect $(\mathrm{P}<0.05)$ for the consumption of the sugarcane silage with $\mathrm{CaO}$ doses in relation to the silage with urea. There was no effect $(\mathrm{P}>0.05)$ among the $\mathrm{CaO}$ silages; no model presented adjustment regression.

There was increasing linear effect $(\mathrm{P}<0.05)$ of the $\mathrm{CaO}$ doses for $\mathrm{ADF}$ intake. In addition, there was only difference between the sugarcane silage with $2.4 \% \mathrm{CaO}$ in relation to the sugarcane silage with urea. On the other hand, there was difference in NFC intake $(\mathrm{P}<0.05)$ only at $1.6 \% \mathrm{CaO}$ when compared with the silage of sugarcane with urea. There was also positive quadratic effect of the $\mathrm{CaO}$ doses on NFC intake, with maximum intake of $0.3252 \mathrm{~kg} /$ day at $1.43 \% \mathrm{CaO}$.

As regards the DM intake (\%LW), the levels of 1.6 and $2.4 \% \mathrm{CaO}$ in the sugarcane silage presented values of 2.59 and $2.72 \%$ of the $\mathrm{LW}$, superior to the intake observed for the sugarcane with addition of urea (Table 4). We can observe that the sugarcane silages subjected to the treatment 
with calcium oxide showed good chemical characteristics, with greater nutrient intake in the diets. The increase in dry matter intake at the doses 0.8 and $1.6 \%$ (Table 3 ) is what was expected in this study. However, when chemical additives are utilized in the treatment of roughages, they do not always promote elevation in nutrient intake and improvements in ruminants. This fact can be related to the elevated alkalinity of the calcium oxide, which might have compromised the palatability of the diet.

The DM intake (\% LW) presented quadratic effect $(\mathrm{P}<0.05)$ (Table 4$)$, with maximum point of $2.83 \%$ of the LW for the dose of $1.72 \% \mathrm{CaO}$. Different results were found by Carvalho (2008), who recorded an intake of 3.9\% of the LW with sugarcane treated with $\mathrm{CaO}$ at the levels $0.0,0.75,1.5$ and $2.25 \%$, for Santa Ines sheep. Likewise, Freitas et al. (2008) reported DM intake of $954.8 \mathrm{~g} \mathrm{DM} /$ day $(3.9 \%$ of the $\mathrm{LW})$ in sheep fed a diet of sugarcane hydrolyzed with 0.5 and $0.9 \% \mathrm{CaO}$ and $50 \%$ concentrate. The authors formulated diets to meet the requirements for the maintenance of animals, with gains of $150 \mathrm{~g} / \mathrm{day}$.

The intakes of CP, TCH, NFC, hemicellulose and TDN (in $\%$ of the $\mathrm{LW}$ ) presented differences $(\mathrm{P}<0.05)$ between the silages with $\mathrm{CaO}$ and with urea (Table 4). The CP intake was lower in all silages when compared with the urea. The intake values of TCH, NFC and TDN presented differences in the treatment with $1.6 \%$ of inclusion of $\mathrm{CaO}$ in the sugarcane, with greater intake of these nutrients in relation to the other treatments. The intakes of NFC and TDN presented quadratic effect $(\mathrm{P}<0.05)$. Possible benefits in the chemical treatment of the sugarcane with $\mathrm{CaO}$ may have promoted elevation in the consumption of these nutrients, through the likely increase in the passage rate.

The NDF presented negative quadratic effect $(\mathrm{P}<0.05)$ with minimum of $0.79 \%$ of the live weight, with the dose of

Table 3 - Means of the least squares of intake of sugarcane silage with different levels of calcium oxide or urea in the natural matter and coefficients of variation

\begin{tabular}{|c|c|c|c|c|c|c|c|}
\hline \multirow[t]{2}{*}{ Item } & \multicolumn{4}{|c|}{$\begin{array}{l}\text { Sugarcane silage with different doses of } \\
\mathrm{CaO} \text { (in } \% \text { of natural matter) }\end{array}$} & \multirow{2}{*}{$\begin{array}{l}\text { Sugarcane } \\
\text { silage with } \\
\text { urea }^{1}\end{array}$} & \multirow{2}{*}{$\begin{array}{l}\mathrm{CV} \\
(\%)\end{array}$} & \multirow[t]{2}{*}{ Equation } \\
\hline & 0.0 & 0.8 & 1.6 & 2.4 & & & \\
\hline & \multicolumn{5}{|c|}{ Intake (kg/day) } & & \\
\hline Dry matter & 0.590 & 0.769 & 0.735 & 0.673 & 0.650 & 18.6 & $\hat{\mathrm{Y}}=\mathrm{ns}$ \\
\hline Crude protein & $0.051 \mathrm{a}$ & $0.054 \mathrm{a}$ & $0.049 \mathrm{a}$ & $0.049 \mathrm{a}$ & 0.070 & 13.7 & $\hat{\mathrm{Y}}=\mathrm{ns}$ \\
\hline Ether extract & 0.007 & 0.010 & 0.010 & 0.008 & 0.010 & 20.5 & $\hat{\mathrm{Y}}=0.00740842+0.00418921 * \mathrm{CaO}-0.00160050 * \mathrm{CaO}^{2}\left(\mathrm{r}^{2}=0.96\right)$ \\
\hline Neutral detergent fiber & 0.318 & 0.327 & 0.303 & 0.278 & 0.333 & 13.2 & $\hat{\mathrm{Y}}=\mathrm{ns}$ \\
\hline Total carbohydrates & 0.511 & 0.657 & 0.604 & 0.554 & 0.529 & 18.7 & $\hat{\mathrm{Y}}=\mathrm{ns}$ \\
\hline Non-fibrous carbohydrates & 0.161 & 0.299 & $0.318 \mathrm{a}$ & 0.248 & 0.202 & 27.3 & $\hat{\mathrm{Y}}=0.162158+0.230425 * \mathrm{CaO}-0.0814038 * \mathrm{CaO}^{2}\left(\mathrm{r}^{2}=0.48\right)$ \\
\hline Hemicellulose & 0.084 & 0.061 & 0.053 & 0.055 & 0.069 & 15.2 & $\hat{\mathrm{Y}}=0.0834668-0.0346756^{* *} \mathrm{CaO}+0.00950594 * * \mathrm{CaO}^{2}\left(\mathrm{r}^{2}=1.00\right)$ \\
\hline Total digestible nutrients & 0.335 & 0.504 & 0.509 & 0.433 & 0.413 & 17.0 & $\hat{\mathrm{Y}}=0.339197+0.267064 * * \mathrm{CaO}-0.0958005^{*} * \mathrm{CaO}^{2}\left(\mathrm{r}^{2}=0.98\right)$ \\
\hline
\end{tabular}

a - differs from control at $5 \%$ probability by the Dunnett test; * - significant at 5\%; ** - significant at 1\% probability; NDFap - neutral detergent fiber corrected for ash and protein ns - not significant; CV - coefficient of variation.

${ }^{1}$ Sugarcane with addition of $1.5 \%$ urea ( $\%$ natural matter).

Table 4 - Means of the intake of sugarcane silage treated with different levels of calcium oxide $(\mathrm{CaO})$ or urea in the natural matter and coefficients of variation

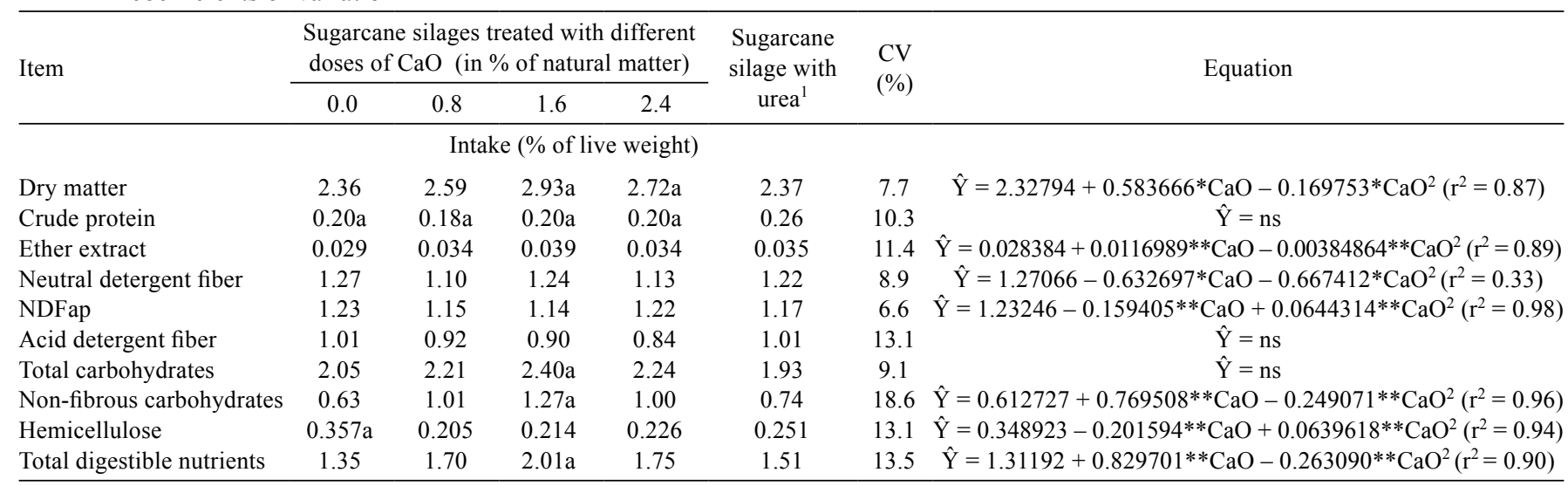

a - differs from control at 5\% probability by the Dunnett test; * - significant at 5\%; ** - significant at $1 \%$ probability; NDFap - neutral detergent fiber corrected for ash and protein; ns - not significant; CV - coefficient of variation.

${ }^{1}$ Sugarcane with addition of $1.5 \%$ urea ( $\%$ natural matter). 
$0.5 \% \mathrm{CaO}$. The same effect was observed for NDFap with minimum of $1.13 \%$ of live weight and a dose of $1.24 \%$ calcium oxide. Non-fibrous carbohydrates presented positive quadratic effect $(\mathrm{P}<0.05)$ with maximum point of $1.21 \%$ of the live weight, with a dose of $1.55 \% \mathrm{CaO}$. Total digestible nutrients presented positive quadratic effect ( $1.97 \%$ of the live weight) for a dose of $1.58 \%$ calcium oxide.

The doses of 0.8 and $1.6 \% \mathrm{CaO}$ showed greater intake in relation to the silage with urea and the untreated silage. The improvement in the chemical composition of the treated sugarcane, promoted by the alkaline additive, possibly promoted decrease in the hemicellulose due to its partial solubilization; the composition of the sugarcane silage presented decrease in the contents of NDF and ADF (Table 2). It is likely that the alkaline environment contributed to increase the digestibility of the sugarcane according to the possible reduction of lignin (Table 2).

Promoting the increase in the intake of sugarcane silage treated with calcium oxide is the interest of nutritionists; however, the effect desired, which is the augmentation of intake, does not always occur. However, simply improving the cell wall components of sugarcane is enough to make it a viable roughage in the feeding of ruminants. Reports published by Santos (2007), who utilized calcium oxide in the sugarcane, showed that it was capable of reducing the concentration of cell wall components with decrease in the NDF and ADF, improving the digestibility coefficient of the dry matter and organic matter, observed in the silages treated with $1.5 \%$ calcium oxide. The authors observed that different doses of quicklime (1.0 and $1.5 \%$ in the natural matter) in sugarcane silages significantly reduced the production of ethanol and promoted greater recovery of dry matter and soluble carbohydrates.

Visually, one could observe in this experiment that certain animals preferred to consume more roughage rather than concentrate, and the opposite was also true, suggesting that the variations occurring during the experiment were merely random. These pieces of evidence are supported by Van Soest (1994), who explains the control of voluntary intake by ruminants through mechanisms of integrated or isolated action of physical factors like physical and physiological satiety and chemical satiety.

It is possible that the animals in this study left lowdigestibility orts, suggesting that, in the diet supplied, what was offered to some animals might have been better than to others, since during the weighing some animals demonstrated having gained more weight in relation to others receiving the same diet. The same happened for the silages treated with calcium oxide, which increased the dry matter intake, in percentage of live weight, up to the dose of $1.6 \%$, which by the effect on the cell wall components improved the intake up to this level, when it decreased again; this was observed in almost all variables analyzed.

The intake of the sugarcane subjected to treatment with alkaline additives, such as the use of calcium oxide levels, is constantly sought, as several authors have observed (Moraes, 2006; Carvalho, 2008); however, the treatment with these additives does not always improve the elevation in the nutrient intake by animals. This happens because certain alterations resulting from the fermentation process affect intake (Huhtanen et al., 2002). In addition to influencing the dry matter intake, the fermentation occurring during the ensilage process may modify the profile of nutrients absorbed by the digestive tract (Huhtanen et al., 2003).

Other relations found by Huhtanen et al. (2002) regarding the ingestion of silage refer to the contents of lactic acid and volatile fatty acids. The authors report the existence of a negative correlation between the concentration of these acids and the consumption of silage, where volatile fatty acids present greater reducing effect on the silage intake than lactic acid, which suggests that homolactic fermentation presents smaller effect on the ingestion of silage than heterolactic fermentation.

The calcium intake in the control treatment was of $10.83 \mathrm{~g} / \mathrm{kg}$ and considering the $\mathrm{CaO}$ doses, there was an increase of $826.52 ; 1,706.47$; and $1,835.58 \%$ for the levels $0.8,1.6$ and $2.4 \%$, respectively. These values are considered high when compared with values formulated in diets for sheep under normal conditions. In this specific case, the addition of calcium oxide at elevated amounts in diets for sheep differs from the recommendation of requirements given by the NRC (1985), which considers an absolute requirement of $183 \mathrm{mg}$ calcium and $103 \mathrm{mg}$ phosphorus $/ \mathrm{kg}$ of live weight for growing lambs, whereas the Agricultural Research Council (ARC, 1980) estimated calcium at $11 \mathrm{~g}$ and phosphorus at $6 \mathrm{~g} / \mathrm{kg}$ of live body weight (LBW). Both institutions admit that the net requirements of macro elements are constant and are not dependent on the weight of the animal.

The ARC (1980) established that the dietary requirements of calcium and phosphorus for sheep of $25 \mathrm{~kg}$ live weight with a daily gain of $100 \mathrm{~g} /$ day are of 1.547 and $0.684 \mathrm{~g} / \mathrm{animal} / \mathrm{day}$; and with a daily gain of $200 \mathrm{~g} / \mathrm{day}$, 3.094 and $1.368 \mathrm{~g} / \mathrm{animal} / \mathrm{day}$, for calcium and phosphorus, respectively. According to their dietary recommendations, the intake of these minerals by the sheep in this study are fairly higher, which possibly interfered with the dry matter intake, and consequently with the nutrient intake. 
In the present study, with the help of the NRC (2006), a weight gain of $150 \mathrm{~g} /$ day was estimated for $24.09 \mathrm{~kg}$ lambs (average weight). Although the estimate was quite different from what was observed, we can infer that sugarcane silages with or without $\mathrm{CaO}$ or urea did not correspond to the expectations of gain predicted. One explanation for the dry matter intake (Table 3 ) being greater for the silages treated with calcium oxide is the partial solubilization of the components of the sugarcane cell wall, which promoted increase in the intakes up to the level 1.6\% calcium oxide.

Pérez et al. (2001) worked with body composition and nutritional requirements of calcium and phosphorus in growing Santa Inês lambs and verified intake of these minerals at 14.143 and $7.117 \mathrm{~g} / \mathrm{kg}$, respectively, for animals of $25 \mathrm{~kg} \mathrm{LW} \mathrm{(21.2} \mathrm{kg} \mathrm{empty} \mathrm{body} \mathrm{weight} \mathrm{-} \mathrm{EBW),} \mathrm{which}$ is quite inferior to the results found herein for calcium $(101.03 \mathrm{~g} / \mathrm{kg})$, but superior for phosphorus $(2.65 \mathrm{~g} / \mathrm{kg})$. The authors conclude that the net requirements of calcium vary between 9.82 and $11.63 \mathrm{~g} / \mathrm{kg} \mathrm{LW}$, and for phosphorus, from 4.28 to $5.82 \mathrm{~g} / \mathrm{kg} \mathrm{LW}$, respectively; these values were higher than those found by the ARC (1980) and the NRC (1985). The difference between intake and excretion of calcium was $12.20,61.65,74.22$ and $64.10 \%$ for the doses $0.0,0.8,1.6$ and $2.4 \%$, respectively, whereas for the phosphorus levels, the excretion was greater than the intake, possibly because there was some imbalance between the minerals and also because of the greater amounts of endogenous phosphorus losses. Louvandini \& Vitti (2007), Bravo et al. (2003a) and Dias et al. (2007) commented that the increase in the phosphorus content in the sheep diet increases its absorption and excretion through the feces, which is the preferential pathway for elimination. Louvandini \& Vitti (2007) claimed that the phosphorus consumed and that present in the urine are associated with the stabilization of the endogenous fecal loss, associated with the excess material ingested and the type of feed ingested, since the greater the effective fiber content ingested, the more salivation and excretion of phosphorus through the feces (Bravo et al., 2003b).

The calcium:phosphorus ratio in the silages with $\mathrm{CaO}$ presented effect $(\mathrm{P}<0.01)$ when compared with the silage with urea. The $\mathrm{CaO}$ doses in the sugarcane silage promoted greater relation between the minerals. The difference in the $\mathrm{CaO}$ intake was observed at the doses $0.8,1.6$ and $2.4 \%$, with calcium:phosphorus ratios of 29.44, 70.47 and 73.6, respectively. The same evidence was observed for the fecal output, showing that there was a decrease in the ratio due to the increase in the fecal excretion of phosphorus (Table 5).

The literature has demonstrated that there is an interrelationship of calcium and phosphorus (Challa et al., 1989) characterized by changes in the calcium metabolism, which can be caused by variations in the levels of phosphorus, and the opposite is also true. Vitti et al. (2006) commented that high values of fecal calcium may indicate lower availability of calcium in the source supplied, causing a greater amount of calcium to pass directly through the digestive tract without absorption, generating big losses.

Table 5 - Intake and excretion of calcium and phosphorus and calcium:phosphorus ratio of sugarcane silage with different doses of calcium oxide $(\mathrm{CaO})$ or urea

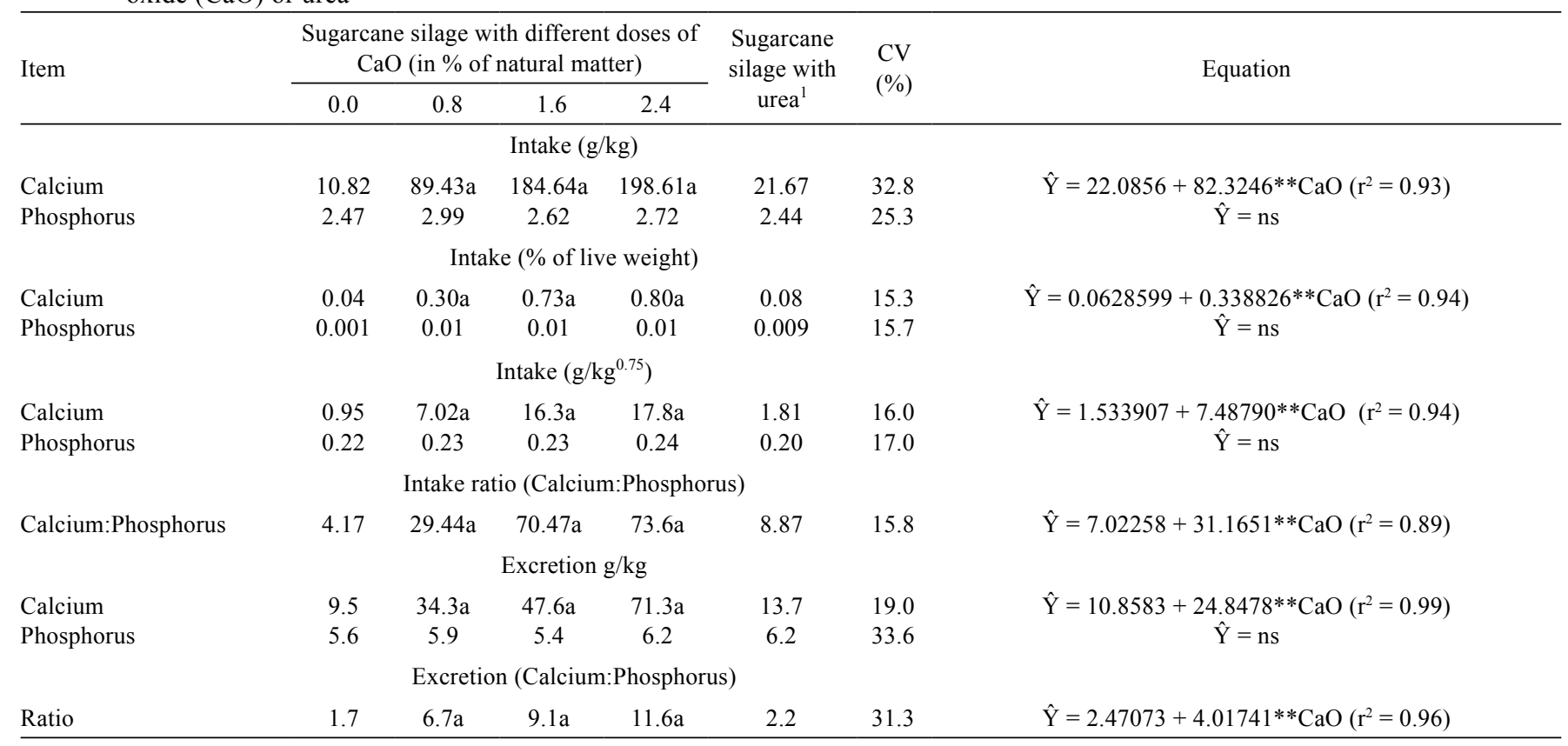

a - differs from control at $5 \%$ probability by the Dunnett test; * - significant at $5 \%$; ** - significant at $1 \%$ probability; ns - not significant; CV - coefficient of variation. ${ }^{1}$ Sugarcane with addition of $1.5 \%$ urea ( $\%$ natural matter). 
The calcium:phosphorus ratio presented positive linear regression, which also occurred for the excretion, which presented higher amounts of phosphorus in the feces than in relation to that consumed, contrarily to the results of Salviano \& Vitti (1998), who verified that the calcium: phosphorus ratio in the plasma was negative and linearly correlated with the amount of endogenous phosphorus excreted in the feces, indicating that at these levels of calcium and phosphorus in the plasma, the more the calcium:phosphorus ratio in the plasma is raised, the more the endogenous phosphorus fecal losses decrease.

According to the adequate levels of dietary phosphorus (NRC, 1980), ruminants can bear such a high calcium: phosphorus ratio that it can reach 7:1 and/or 2 per cent of calcium in the diet. However, the long-term ingestion of phosphorus at levels that represent 2 to 3 times the requirements for maintenance can cause increase in bone resorption in adult animals and decrease the calcium: phosphorus ratio $(<2: 1)$, possibly contributing to an increase in the incidence of urolithiasis in intact and castrated sheep. Even with inclusion of $1 \%$ mineral salt in the diet, which allowed for a ratio of 2.4:1 between these two minerals, the addition of calcium oxide as chemical additive considerably elevated their levels so as to preserve the ensiled sugarcane, causing imbalance in the ratio of minerals, which possibly interfered in the animal performance and worsened as the doses increased.

According to Salviano \& Vitti (1998), the calcium: phosphorus ratio of 1.5:1.0 is considered the best, and the addition of more calcium to the diet (3.0:1.0) does not bring any benefit in terms of phosphorus absorption or efficiency of absorption.

There was no difference $(\mathrm{P}>0.05)$ for the digestibility of DM, EE, NDF, ADF and TDN for the silages with different $\mathrm{CaO}$ doses in relation to the silage with urea, while EE presented increasing linear regression and $\mathrm{CP}$ did not show any difference $(\mathrm{P}>0.05)$ of the sugarcane silages with different $\mathrm{CaO}$ doses in relation to the silage with urea (Table 6). There was difference $(\mathrm{P}<0.01)$ between the silages with different levels of $\mathrm{CaO}$ for the digestibility of TCH and NFC, in relation to the silages with urea. The total carbohydrates presented increasing quadratic effect with maximum point of $81.9 \%$ digestibility for a dose of $1.77 \% \mathrm{CaO}$, and increasing linear effect for NFC. In contrast, Carvalho (2008) observed decrease in DM as the $\mathrm{CaO}$ doses in sugarcane increased, and Pires et al. (2004a) stated that the alkaline treatment positively influences the DM digestibility.

According to Carvalho (2008), it is possible that the elevation in the $\mathrm{pH}$ of sugarcane treated with $\mathrm{CaO}$ caused a deleterious effect on the rumen microorganisms, reducing the DM digestibility coefficients. Yet, in the present study, it is necessary to emphasize that there was no difference in DM intake in $\mathrm{kg} /$ day.

Rocha Júnior et al. (2003) found $18.43 \%$ digestibility for the NDF of fresh sugarcane and Campos et al. (2010) verified greater nutrient intake in diets based on fresh sugarcane silage $(\mathrm{NDF}=48.87 \%)$.

Pontes (2007) verified that the use of calcium oxide did not affect the digestibility of total carbohydrates. Balieiro Neto et al. (2007) observed that the sugarcane silages treated with calcium oxide showed the highest digestibility values with greater NFC content and Balieiro Neto et al. (2009) verified average NFC in vitro dry matter digestibility of $67 \%$ with the use of $0.5 \%$ lime. The NFC intake values obtained in this study increased up to the dose of $1.6 \%$ $\mathrm{CaO}$, but reduced with the addition of $2.4 \%$.

There was difference $(\mathrm{P}<0.05)$ for daily weight gain (g/day) at the dose $0.8 \% \mathrm{CaO}$, concerning the performance characteristics of sheep fed silages with different $\mathrm{CaO}$ levels in relation to the silage with urea. Daily weight gain presented increasing quadratic effect with maximum of $73.26 \mathrm{~g} /$ day for $1.15 \% \mathrm{CaO}$. Feed efficiency was $8.8 \mathrm{~g} / \mathrm{kg}$ and feed conversion was $10.87 \mathrm{~kg} \mathrm{DM} / \mathrm{kg}$ produced (Table 7).

Table 6 - Digestibility of nutrients from the sugarcane silage treated with different doses of calcium oxide $(\mathrm{CaO})$ or urea

\begin{tabular}{|c|c|c|c|c|c|c|c|}
\hline \multirow[t]{2}{*}{ Item } & \multicolumn{4}{|c|}{$\begin{array}{l}\text { Sugarcane silage with different } \mathrm{CaO} \\
\text { doses (in } \% \text { of natural matter) }\end{array}$} & \multirow{2}{*}{$\begin{array}{c}\text { Sugarcane } \\
\text { silage with } \\
\text { urea }^{1}\end{array}$} & \multirow{2}{*}{$\begin{array}{l}\text { CV } \\
(\%)\end{array}$} & \multirow[t]{2}{*}{ Equation } \\
\hline & 0.0 & 0.8 & 1.6 & 2.4 & & & \\
\hline \multicolumn{8}{|c|}{ Digestibility (\%) } \\
\hline Dry matter & 61.5 & 68.4 & 69.1 & 67.2 & 63.9 & 6.5 & $\hat{\mathrm{Y}}=\mathrm{ns}$ \\
\hline Crude protein & $50.7 \mathrm{a}$ & $49.2 \mathrm{a}$ & $44.6 \mathrm{a}$ & $46.2 \mathrm{a}$ & 65.3 & 16.1 & $\hat{\mathrm{Y}}=\mathrm{ns}$ \\
\hline Ether extract & 60.1 & 65.9 & 70.9 & 71.1 & 68.3 & 10.2 & $\hat{\mathrm{Y}}=61.3436+4.73240 * * \mathrm{CaO}\left(\mathrm{r}^{2}=0.89\right)$ \\
\hline Neutral detergent fiber & 49.8 & 54.7 & 55.6 & 56.5 & 51.9 & 11.0 & $\hat{\mathrm{Y}}=\mathrm{ns}$ \\
\hline Acid detergent fiber & 52.8 & 54.1 & 52.1 & 56.6 & 51.6 & 9.6 & $\hat{\mathrm{Y}}=\mathrm{ns}$ \\
\hline Total digestible nutrients & 49.8 & 54.7 & 55.6 & 56.5 & 51.9 & 11.0 & $\hat{\mathrm{Y}}=\mathrm{ns}$ \\
\hline Total carbohydrates & 64.2 & $74.5 \mathrm{a}$ & $75.2 \mathrm{a}$ & $75.6 \mathrm{a}$ & 64.8 & 4.5 & $\hat{\mathrm{Y}}=64.6201+13.6194 * * \mathrm{CaO}-3.84347 * * \mathrm{CaO}^{2}\left(\mathrm{r}^{2}=0.95\right)$ \\
\hline Non-fibrous carbohydrates & 87.3 & 93.9 & 95.3 & 95.2 & 87.0 & 4.3 & $\hat{\mathrm{Y}}=89.1812+3.13080 * * \mathrm{CaO}\left(\mathrm{r}^{2}=0.72\right)$ \\
\hline
\end{tabular}

a - differs from control at $5 \%$ probability by the Dunnett test; * - significant at $5 \%$; ** - significant at $1 \%$ probability; ns - not significant; CV - coefficient of variation ${ }^{1}$ Sugarcane with addition of $1.5 \%$ urea ( $\%$ natural matter). 
Table 7 - Daily weight gain and feed efficiency and conversion of sheep fed sugarcane silage with calcium oxide (CaO) or urea and coefficient of variation

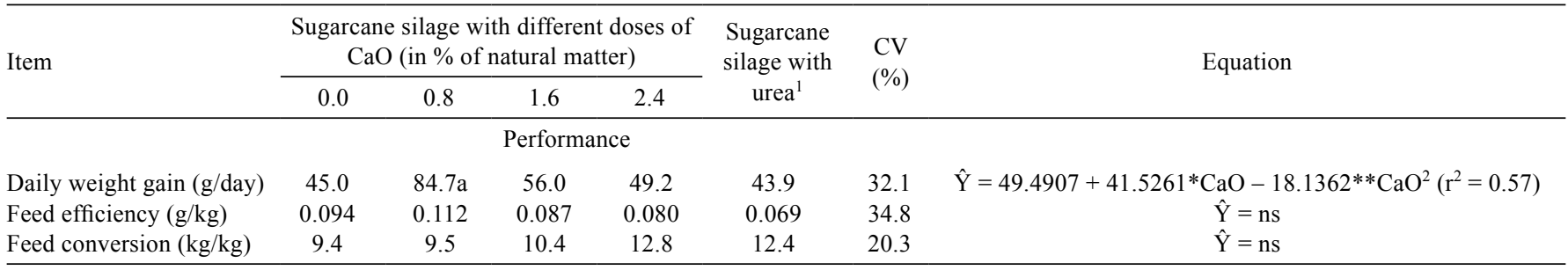

a - differs from control at $5 \%$ probability by the Dunnett test; * - significant at $5 \%$; ** - significant at $1 \%$ probability; ns - not significant; CV - coefficient of variation.

${ }^{1}$ Sugarcane with addition of $1.5 \%$ urea (\% natural matter).

These results were inferior to the expected and estimated, probably not only because of the diet with sugarcane, which is a roughage that presents nutritional characteristics below the requirement of certain animal categories, but also because of the possible imbalance from the high concentration of calcium and the disproportional calcium:phosphorus ratio.

Several factors were determinant for the low performance of these animals: the maturity stage of the sugarcane (age); the fermentation process, which might have reduced the soluble carbohydrates with the production of ethanol, decreasing intake; and especially the imbalance in the levels of calcium and its relation with phosphorus, among other non-evident factors.

\section{Conclusions}

Diets containing sugarcane silage with up to $0.8 \%$ calcium oxide in the feeding of sheep partially improves weight gain; however, doses above this percentage or sugarcane silage with urea decrease the intake and digestibility of dry matter, neutral detergent fiber and total digestible nutrients.

\section{References}

AGRICULTURAL RESEARCH COUNCIL - ARC. (Farnham Royal, Inglaterra). The nutrient requirements of farm livestock. Wallingford: CAB International, 1980. 351p.

AMARAL, R.C. Avaliação de aditivos químicos sobre as perdas e o valor alimentício das silagens de cana-de-açúcar para ovinos. 2007. 165f. Dissertação (Mestrado em Ciência Animal e Pastagens) - Escola Superior de Agricultura "Luiz de Queiroz", Universidade de São Paulo, Piracicaba.

ANDRADE, J.B.; FERRARI JÚNIOR, E.; POSSENTI, R.A. et al. Valor nutritivo da silagem de silagem, de cana-de-açúcar, cortada aos 7 meses de idade, tratada com ureia e adicionada de rolão de milho. In: REUNIÃO ANUAL DA SOCIEDADE BRASILEIRA DE ZOOTECNIA, 38., 2001, Piracicaba. Anais... Piracicaba: SBZ, 2001 [CD-ROM].

BALIEIRO NETO, G.; FERRARI JUNIOR, E.; NOGUEIRA, J.R. et al. Perdas fermentativas, composição química, estabilidade aeróbia e digestibilidade aparente de silagem de cana-de-açúcar com aditivos químico e microbiano. Pesquisa Agropecuária Brasileira, v.44, n.6, p.621-630, 2009.
BALIEIRO NETO, G.; SIQUEIRA, G.R.; REIS, R.A. et al. Óxido de cálcio como aditivo na ensilagem de cana-de-açúcar. Revista Brasileira de Zootecnia, v.36, n.5, p.1231-1239, 2007.

BEZERRA, E.S.; QUEIROZ, A.C.; BEZERRA, A.R.G.F. et al. Perfil granulométrico da fibra dietética sobre o tempo médio de retenção e a digestibilidade aparente de dietas para vacas leiteiras Revista Brasileira de Zootecnia, v.33, n.6, p.2378-2386, 2004 (supl. 3).

BRAVO, D.; SAUVANT, D.; BOGAERT, C. et al. II: Quantitative aspects of phosphorus absorption in ruminants. Reproduction and Nutrition Development, v.43, p.271-284, 2003a.

BRAVO, D.; SAUVANT, D.; BOGAERT, C. et al. III: Quantitative aspects of phosphorus excretion in ruminants. Reproduction and Nutrition Development, v.43, p.285-300, 2003b.

CABRAL, L.S.; VALADARES FILHO, S.C.; ZERVOUDAKIS, J.T. et al. Degradabilidade in situ da matéria seca, da proteína bruta e da fibra de alguns alimentos. Pesquisa Agropecuária Brasileira, v.40, n.8, p.777-781, 2005.

CAMPOS, P.R.S.S.; VALADARES FILHO, S.C.; DETMANN E. et al. Consumo, digestibilidade e estimativa do valor energético de alguns volumosos por meio da composição química Revista Ceres, v.57, n.1, p.79-86, 2010

CAPELLE, E.R.; VALADARES FILHO, S.C.; SILVA, J.F.C. et al. Estimativas do valor energético a partir de características químicas e bromatológicas dos alimentos Revista Brasileira de Zootecnia, v.30, n.6, p.1837-1856, 2001.

CARVALHO, G.G.P. Cana-de-açúcar tratada com óxido de cálcio em dietas para ovinos, caprinos, novilhas e vacas em lactação. 2008. 279f. Tese (Doutorado em Zootecnia) - Universidade Federal de Viçosa, Viçosa, MG.

CARVALHO, G.G.P.; PIRES, A.J.V.; SILVA, R.R. et al. Comportamento ingestivo de ovinos alimentados com dietas compostas de silagem de capim-elefante amonizado ou não e subprodutos agroindustriais. Revista Brasileira de Zootecnia, v.35, n.4, p.1805-1812, 2006a.

CARVALHO, G.G.P.; PIRES, A.J.V.; VELOSO, C.M. et al. Valor nutritivo do bagaço de cana-de-açúcar amonizado com quatro doses de ureia. Pesquisa Agropecuária Brasileira, v.41, n.1, p.125-132, 2006b.

CASALI, A.O. Procedimentos metodológicos in situ na avaliação do teor de compostos indigestíveis em alimentos e fezes de bovinos. 2006. 47f. Dissertação (Mestrado em Zootecnia) Universidade Federal de Viçosa, Viçosa, MG.

CHALLA, J.; BRAITHWAITE, G.D.; DHANOA, M.S. Phosphorus homoeostasis in growing calves. Journal of Agricultural Science, v.112, p.217-226, 1989

DIAS, R.S.; KEBREAB, E.; VITTI, D.M.S.S. et al. Phosphorus kinetics in lambs fed differents levels of dicalcium phosphate. Journal of Agricultural Science, v.145, p.509-516, 2007.

FREITAS, A.W.P.; ROCHA, F.C.; ZONTA, A. et al. Consumo de nutrientes e desempenho de ovinos alimentados com dietas à base de cana-de-açúcar hidrolisada Pesquisa Agropecuária Brasileira, v.43, n.11, p.1569-1574, 2008.

HALL, M.B. Challenges with non-fiber carbohydrate methods. Journal of Animal Science, v.81, n.12, p.3226-3232, 2003. 
HUHTANEN, P.; NOUSIAINEN, J.I.; KHALILI, H. et al. Relationships between silage fermentation characteristics and milk production parameters: analyses of literature data. Livestock Production Science, v.81, p.57-73, 2003.

HUHTANEN, P.; KHALILI, H.; NOUSIAINEN, J.I. et al. Prediction of the relative intake potential of grass silage by dairy cows. Livestock Production Science, v.72, p.111-130, 2002.

LOUVANDINI, H.; VITTI, D.M.S.S. Cinética de fósforo com modelos matemáticos em ovinos adultos. Pesquisa Agropecuária Brasileira, v.42, n.10, p.1467-1472, 2007.

MERTENS, D.R. Gravimetric determination of amylase-treated neutral detergent fiber in feeds with refluxing in beakers or crucibles: collaborative study. Journal of AOAC International, v.85, p.1217-1240, 2002.

MORAES, K.A.K. Desempenho produtivo de novilhas de corte alimentadas com cana-de-açúcar tratada ou não com óxido de cálcio e diferentes ofertas de concentrados. 2006. 60f. Dissertação (Mestrado em Zootecnia) - Universidade Federal de Viçosa, Viçosa, MG.

NATIONAL RESEARCH COUNCIL - NRC. Mineral tolerance of domestic animal. Washington, D.C.: National Academy of Science, $1980.577 \mathrm{p}$.

NATIONAL RESEARCH COUNCIL - NRC. Nutrient requirements of domestic animals: nutrient requirements of sheep. 6.ed. Washington: National Academy Press, 1985. 117p.

NATIONAL RESEARCH COUNCIL - NRC. Nutrient requirements of small ruminants. 1.ed. Washington: National Academy Press, 2006. 362p.

OLIVEIRA, A.S.; CAMPOS, J.M.S.; VALADARES FILHO, S.C. et al. Substituição do milho por casca de café ou de soja em dietas para vacas leiteiras: consumo, digestibilidade dos nutrientes, produção e composição do leite. Revista Brasileira de Zootecnia, v.36, n.4, p.1171-1182, 2007a.

OLIVEIRA, M.D.S.; ANDRADE, A.T.; BARBOSA, J.C. et al. Digestibilidade da cana-de-açúcar hidrolisada, in natura e ensilada para bovinos. Ciência Animal Brasileira, v.8, n.1, p.41-50 2007b.

ØRSKOV, E.R.; DeB HOVELL, F.D.; MOULD, F. The use of the hylon bag technique for the evaluation of feedstuffs. Tropical Animal Production, v.5, n.3, p.195-213, 1980.

PÉREZ, J.R.O.; GERASEEV, L.C.; SANTOS, C.L. et al. Composição corporal e exigências nutricionais de cálcio e fósforo de cordeiros Santa Inês em crescimento. Pesquisa Agropecuária Brasileira, v.36, n.5, p.815-822, 2001.

PIRES, A.J.V.; GARCIA, R.; VALADARES FILHO, S.C. et al. Novilhas alimentadas com bagaço de cana-de-açúcar tratado com amônia anidra e, ou, sulfeto de sódio. Revista Brasileira de Zootecnia, v.33, n.4, p.1078-1085, 2004a.

PIRES, A.J.V.; GARCIA, R.; VALADARES FILHO, S.C. et al. Degradabilidade do bagaço de cana-de-açúcar tratado com amônia anidra e, ou, sulfeto de sódio Revista Brasileira de Zootecnia, v.33, n.4, p.1071-1077, 2004b.

PONTES, R.A.M. Cana-de-açúcar in natura ou ensilada com oxido de cálcio e ureia em dietas de ovinos. 2007. 60f. Dissertação (Mestrado em Zootecnia) - Universidade Federal de Viçosa, Viçosa, MG.

RESENDE, F.D.; SIGNORETTI, R.D.; COAN, R.M. et al. Terminação de bovinos de corte com ênfase na utilização de volumosos conservados. In: SIMPÓSIO DE VOLUMOSO NA PRODUÇÃO DE RUMINANTES, 2., 2005, Jaboticabal. Anais... Jaboticabal: FUNEP, 2005. p.83-106.

RIBEIRO JUNIOR, J.I. Análise estatística no SAEG (Sistema para análise estatística). Viçosa, MG: UFV, 2001. 301p.

ROCHA JÚNIOR, V.R.; VALADARES FILHO, S.C.; BORGES, A.M. Determinação do valor energético de alimentos para ruminantes pelo sistema de equações. Revista Brasileira de Zootecnia, v.32, n.2, p.473-479, 2003.

SALVIANO, L.M.C.; VITTI, D.M.S.S. Influência da proporção de cálcio e fósforo na dieta, nas perdas endógenas e na absorção de fósforo em ovinos. Pesquisa Agropecuária Brasileira, v.33, n.3, p.218-225, 1998.

SANTOS, M.C. Aditivos químicos para o tratamento da cana-deaçúcar in natura e ensilada (Saccharum officinarum L.). 2007. 112f. Dissertação (Mestrado em Ciência Animal e Pastagens) Escola Superior de Agricultura "Luiz de Queiroz", Universidade de São Paulo, Piracicaba.

SILVA, D.J.; QUEIROZ, A.C. Análise de alimentos: métodos químicos e biológicos. Viçosa, MG: Universidade Federal de Viçosa, 2002. $235 \mathrm{p}$.

SNIFFEN, C.J.; O'CONNOR, D.J.; VAN SOEST, P.J. et al. A net carbohydrate and protein system for evaluating cattle diets: carbohydrate and protein availability. Journal of Animal Science, v.70, n.12, p.3562-3577, 1992.

VAN SOEST, P.J. Nutirtional ecology of the ruminant. 2.ed. New York: Cornell University Press, 1994. 476p.

VITTI, D.M.S.S.; ROQUE, A.P.; DIAS, R.S. et al. Metabolismo de cálcio em ovinos em crescimento sob suplementação com diferentes fontes de cálcio: aplicação e comparação de dois modelos matemáticos. Revista Brasileira de Zootecnia, v.35, n.6, p.2487-2495, 2006. 